\title{
Critical Learnership: A New Perspective on Learning
}

\author{
Jay Hays \\ Institute of Management Technology \\ Dubai, United Arab Emirates \\ Hayo Reinders \\ Unitec Institute of Technology \\ Auckland, New Zealand
}

\begin{abstract}
To keep abreast of technological innovations, social change, and advances in subject matter knowledge, professional practitioners must continually learn. To solve new and different problems and capitalise on emerging opportunities that arise in practice requires learning. Tendencies to learn and solve problems on one's own are limiting and unsustainable. Thus, more collaborative, extensible, and sustainable approaches to learning and change are necessary. To this end, the authors present an emerging perspective on sustainable and collaborative learning, innovation, and transformation-Critical Learnership. Critical Learnership involves shared and continuous critique and challenge of existing ways of thinking, doing, and being, while building autonomy and self-direction. It draws on theories and principles of adult learning and professional development, sustainability and ecology, adaptive systems, organisational learning, and selfdetermination. At its essence, Critical Learnership is a critical, active mindset towards finding sustainable solutions to everyday problems. The skills and strategies of Critical Learnership are necessary for and help to achieve lifelong and life-wide learning. The article lays out the need for a new direction in the way we attempt to understand and encourage learning, describes how Critical Learnership may enable us to venture down this path, and discusses its implications for individuals, organisations, and society as a whole.
\end{abstract}

Keywords: Agency; Leadership; Learning; Sustainability; Professional Practice.

\section{Introduction}

Critical Learnership is an emerging perspective on sustainable learning, innovation, and transformation. It involves continual and deliberate critique and challenge of existing ways of thinking, doing, and being. Critical Learnership 
sets out to make workplaces and communities healthier and more resilient by building the individual and collective capacities and dispositions required for self-governance. Thus, it may be an essential feature of a democratic society, promoting such crucial attributes as agency, autonomy, and responsibility. These key capacities and dispositions are presented in Figure 1, Key Dimensions of Critical Learnership.

While further defined and explained in the body of this article, by way of introduction, Critical Learnership involves equipping individuals and teams with the critical skills to identify what needs, or is worthwhile, to be learned, unlearned, or reinvented; structure and carry-out learning projects; critique and learn from the experience; and take on new and different challenges in ongoing, self-directing, and sustainable ways. It does this through incorporating and leveraging a range of key concepts, theories, and practices that, while individually relatively well-established and understood, have not to date been wholly integrated or exploited. In elaborating their emerging model, the authors draw from literatures spanning adult learning and professional development, sustainability and ecology, adaptive systems, organisational learning, and others.

The learning involved in and produced by Critical Learnership is essential to sustainable practice improvement, organisational innovation, and social change. It engages a continuous process of individual and team renewal and reinvention. This construction and reconstruction of ways of doing and being is necessary to respond to change, and, more importantly, to anticipate and prepare to capitalise upon opportunities and effectively contend with challenges that might arise. Critical Learnership is, fundamentally, a model of individual, professional practice, ${ }^{1}$ and social transformation, founded on the best of what we know about how people learn and change, and within the context of an environment appreciably more complex, vulnerable, and diminished than we ever thought possible.

Designed to be both responsive to current needs and to prepare individuals and teams for problems and opportunities that may arise, Critical Learnership is relevant and likely to be perceived of as valuable by professional practitioners. Critical Learnership balances immediate learning objectives with achieving learning outcomes that contribute to the greater good and long-term sustainability. Critical Learnership is about capacity-building ${ }^{2}$ more than instrumental learning. It is like investing for the future, rather than indulging

\footnotetext{
${ }^{1}$ For more on professional practice of relevance see Nixon and Murr (2006). Germane is also the article by Avis and Freshwater (2006) on the roles of Critical Thinking and Critical Reflection in expert practice, and the work by Dunne (2015).

2 See Hawe et al. (1997) or Potter and Brough (2004) for useful depictions of capacitybuilding. Whilst there is much more to it than this, capacity-building serves to empower target individuals and groups and sustainability of initiatives (Disterheft et al., 2015).
} 
now with earnings. It is concerned not just with what is, but with what might be, and as such is wise and sustainable learning. ${ }^{3}$

Critical Learnership seeks to reduce the tendencies (and drivers) to shortcut, compromise, or postpone scrupulous solutions and decisions in favour of the preferred (preferred often being perceived as faster, cheaper, less risky, politically popular, more predictable, and the like). Not only do solutions and decisions arrived at through cursory means run the risk of proving untenable (see Cooksey, 2003), but the potential value of the learning generated by critical problem-solving and analysis evaporates. Critical Learnership would have problems and opportunities of practice explored systematically, methodically, and objectively; and, to the fullest extent possible, through the lenses of multiple perspectives.

\section{The Case for Learning}

To keep abreast of technological innovations, social change, and advances in subject matter knowledge, professional practitioners must continually learn. At the same time, to solve new and different problems and capitalise on emerging opportunities that arise in practice requires learning as well. Moreover, to do things differently and better-to innovate and change-demands learning (Cörvers, 2016; Hargadon, 2002).

This is a big ask on top of intense and exhausting workloads, exacerbated by the relentless demand to do more with less, inevitable staffing shortages, and dwindling resources for professional development. Under such conditions, we are driven to take shortcuts, ${ }^{4}$ make compromises, and attend to the yet next seeming urgent crisis; each of which, while understandable, may have costly repercussions down the line. These and other responses to pressure and turmoil impede accuracy, clarity, diligence, inclusiveness, and other elements of the careful forethought and analysis needed to contend effectively with big issues. Creativity, for example, a contributor to innovation and requisite for the solution of many complex problems, is unlikely to be tapped when individuals are feeling pressured, overstretched, or vexed (Davis, 2009; Reiter-Palmon and Illies, 2004). ${ }^{5}$

If the above were not grave enough, scholars, industry leaders, and government officials acknowledge failings in our education systems to produce graduates who demonstrate competent levels of initiative, autonomy, critical thinking, and other key skills and dispositions associated with the life-wide and lifelong learning thought necessary in the complex, global world of the $21^{\text {st }}$ Century (Hays, 2015).

\footnotetext{
3 See Ramirez (2012), Richards (2015), or Rowley and Gibbs (2008) for more on sustainable learning and linkages to wisdom.

${ }^{4}$ And sometimes reassuringly advised to do so (see Hoy and Tarter, 2010).

${ }^{5}$ See Funke et al. (2018) or Mitchell and Walinga (2017) for most recent discussions on factors in creative problem-solving.
} 
Given the above,

1. Learning is an essential aspect of professional practice.

2. It is not always easy to find time or focus for learning.

3. It is doubtful that professional development opportunities can or will always be provided that are timely and relevant.

4. The pace and scale of change are so great that predicting what skills and knowledge will be needed in the future is difficult.

5. Failure to learn is a failure of professional practice (at the individual, practice, or organisational, level).

6. To improve what and how we learn, we must change our professional practices and the way we practice.

7. To determine what and how to change practice sustainably and productively also requires learning. So, where to begin?

To address these challenges, the authors have developed Critical Learnership as an approach to learning that can be applied at individual and team levels. Even organisations and communities can adapt and incorporate many of the values, strategies, and principles embodied in the approach. Critical Learnership is a way of thinking about and restructuring the way we approach learning. It is intentional, focused, and strategic. It builds and relies upon individual (and team) self-direction and autonomy, agency, and initiative. ${ }^{6}$ It is empowering and enabling, placing both responsibility and tools for learning in the hands of learners, and equipping them to wield control and means effectively.

\section{Critical Times Call for Critical Measures}

Ambiguity. Crisis. Dilemma. Paradox. Turmoil. Urgency. These and similar terms characterise the complex and often troubling times confronting us today. The scope of problems and their multifarious nature make solutions seemingly impossible. They are-as have come to be called - "wicked" (Camillus, 2008; Hays, 2013). Problems are persistent or recurring-it is clear that they can't be solved using strategies of the past, or they would have been solved already (Richmond, 1993). To complicate matters, many attempted remedies have unanticipated consequences, worsening the situation or disrupting things elsewhere (Sveiby et al., 2009). This is because things are much more connected and entangled than we would like to admit, their interrelationships deeper, more subtle, and far-reaching than we fathom (McGregor, 2012; Montoya, et al., 2006). Linkages exists amongst and across people, places, events, processes - all kinds of species and phenomena, really, what we refer to as "ecological thinking", following Flood (2010), Selby (2000) and others. We don't often think about this; and it is a daunting proposition to do so. Understanding and

6 Relevant sources on these topics include Derrick and Carr (2003), Kreber (1998), McLoughlin and Lee (2008). 
attempting to incorporate interrelatedness in problem-solving and decisionmaking is an aspiration of Critical Learnership.

It is not all bad. There are abundant opportunities. Improvements to quality of life are virtually infinite. But, which ones should we pursue, given increasingly scarce resources and the time and money available? What is going to give us the greatest return on investment? In a world of competing agendas, how do we set priorities that are beneficial and agreeable to the greatest number of diverse stakeholders? And, given that many of us want to make a positive difference in the world, how can we balance the greatest good and long-term sustainability with immediate concerns and interests??

Sometimes with the best of intentions, we busy ourselves but accomplish little or our work is counterproductive to what we or someone else could or should be doing (Conway and Futures, 2009). Time and attention are too precious to waste this way. Paradoxically, in some cases, doing nothing may be the best course of action (Hoy and Tarter, 2010). Ideas and initiatives, like seeds, need time to germinate. However, hiatus can be an impractical, unproductive loss of momentum. The middle ground between busyness and inactivity provides the time, space, and energy for purposeful productivity. But, how do we best fill that space and time, and utilise the energy available? And, how do we know we are using that time, space, and energy productively and effectively? These are questions of Critical Learnership.

\section{Critical Learnership}

The authors have coined the term "Critical Learnership" to call attention to and unify aspects and strategies of purposeful, continuous learning and innovation. In this article we "unpack" the Critical Learnership construct, and demonstrate that the constituent parts, in and of themselves significant, are even more powerful when integrated.

We start with a working definition:

Critical Learnership is a perspective of learning incorporating and governing strategies and values oriented toward sustainability, innovation, and transformation. It involves continual and deliberate critique and challenge of existing ways of thinking, doing, and being, and unlearnings and supplanting these when found to limit our ability to solve problems and capitalise upon opportunities that arise. Critical Learnership sets out to make workplaces and communities healthier and more resilient by building the individual and collective capacities and dispositions required for self-governance. Whilst Critical Learnership applies to the individual level, it is

\footnotetext{
7 Jepson's (2001) article provides helpful background on greater good and sustainability. 8 Amongst references for unlearning are Becker (2005) and Hays (2015) cited elsewhere herein, and Martins et al. (2017).
} 
essentially a collaborative approach to learning and change, which is crucial to its sustainability.

We explicate this encompassing definition further on in this section.

To our knowledge, Critical Learnership as we define it has not been discussed elsewhere. A Google Scholar search reveals not one mention of the tandem term, and even a Google search produced only one citation (Kahn, 2006), which we mention here out of respect for the author and as the citation serves a dual purpose. While the construct "Critical Learnership" is new or at least seldom discussed, it draws from a range of established theories, concepts, and principles, and applications. These include sustainability, resilience, transformation, organisational learning, unlearning, capacity-building, adaptive capacity, critical reflection, self-directed learning, agency, and others.

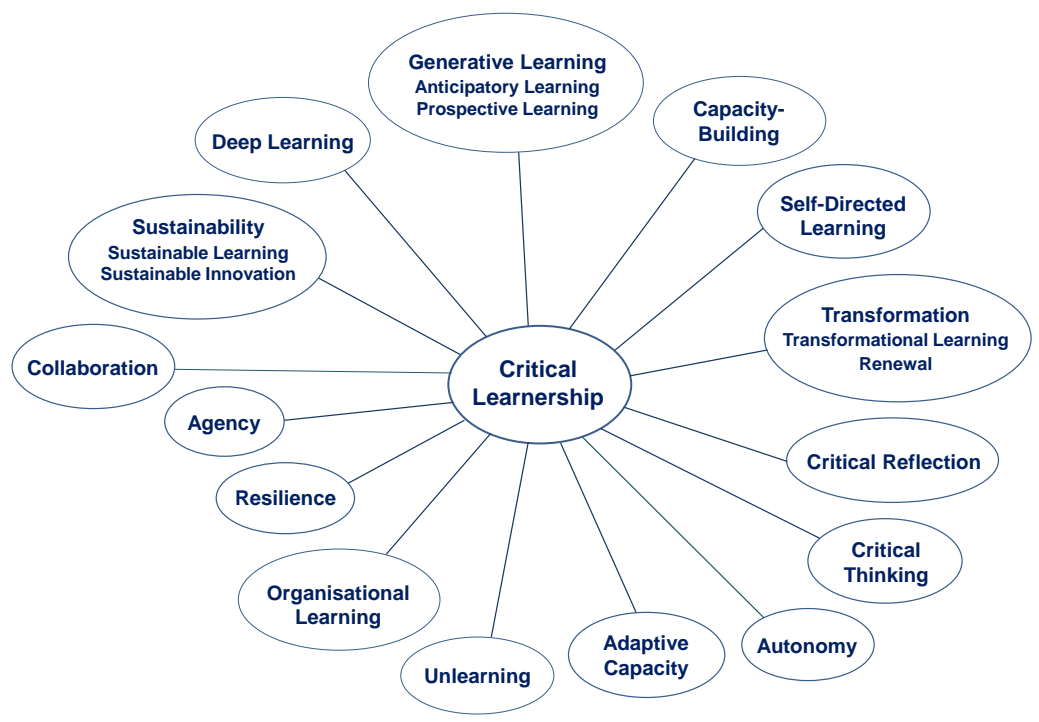

Figure 1. Key Dimensions of Critical Learnership.

The term "learnership" is broadly used in South Africa to describe a suite of educational initiatives designed to better equip graduates for productive employment and to upskill people already in the workforce. This is not, in general, the way we use the term, and we do not attempt to explain or draw from the South African usage, though that should be acknowledged.ii

Designed to be both responsive to current needs and to prepare individuals and teams for problems and opportunities that may arise, Critical Learnership is relevant and likely to be perceived of as valuable by professional practitioners. On the other hand, Critical Learnership may not appear to be efficient in the short-term. It may take more time and more effort than people would like; and in the near-term seem more costly, because it balances immediate learning objectives with achieving learning outcomes that contribute to the greater good 
and long-term sustainability. Critical Learnership is about capacity-building ${ }^{9}$ more than instrumental learning. It is like investing for the future, rather than indulging now with earnings. In fact, a fundamental goal of Critical Learnership is to cultivate abiding respect and discipline for thinking and learning more deeply, more encompassingly, and further into the future. It is concerned not just with what is, but with what might be. Critical Learnership is wise and sustainable learning, ${ }^{10}$ an assertion about which we say more further on.

Critical Learnership seeks to reduce the tendencies (and drivers) to shortcut, compromise, or postpone scrupulous solutions and decisions in favour of the preferred (preferred often being perceived as faster, cheaper, less risky, politically popular, more predictable, and the like). Not only do solutions and decisions arrived at through cursory means run the risk of proving untenable (see Cooksey, 2003), but the potential value of the learning generated by critical problem-solving and analysis evaporates. Critical Learnership would have problems and opportunities of practice explored systematically, methodically, and objectively; and, to the fullest extent possible, through the lenses of multiple perspectives.

\section{Learnership in the Literature}

Learnership has been talked about, if rarely, since at least the early 1990s. Murphy and Toomey (1993), for instance, put forward a learnership / leadership model built on notions of development and interdependence, a model they suggested would be important for developing next-generation learners and leaders. In their model, Murphy and Toomey (1993) emphasise the importance of lifelong learning and learning to learn. Learning is necessary to become an effective leader and effective leaders promote learning in others. Interestingly, these scholars suggest that outstanding learners and leaders both show capacities for creativity, problem-solving, decision-making, and serving as change agents. These would surely be part of a curriculum for learnership.

Similarly, in 1994, Carter and Townsend introduced the notion of learnership as a facet of leadership, asserting that learners are and become leaders. For these scholars, learning lies at the heart of leadership development, and the leader's role is to promote environments conducive to learning. Learning is essential to innovation, they maintain, and evidenced in the pursuit of learning. Such learners are self-directed, purposeful, and autonomous; they seek "selfinvention, self-discovery, and self-development" (p. 50).

Somewhat later, Cooksey (2003) claimed to introduce a new concept, process, and attitude he called learnership. For him, learnership is a capability developed over time that enables the active pursuit of adaptation and success. This

\footnotetext{
9 See Hawe et al. (1997) or Potter and Brough (2004) for useful depictions of capacitybuilding. Whilst there is much more to it than this, capacity-building serves to empower target individuals and groups and sustainability of initiatives.

10 See Ramirez (2012) or Rowley and Gibbs (2008) for more on sustainable learning and linkages to wisdom.
} 
heightened form of learning is essential in complex organisations contending with constant change and an environment of uncertainty. It is a metacognitive ability and consciousness about learning and how it transpires, and a mindful strategic approach to learning. Learnership involves, according to Cooksey, a continuous, cyclic process of meaning-making, validation and reconstruction. He sees learnership as the great equaliser: as greater numbers of employees (and engaged citizens) embrace learning as their responsibility and adopt the habits of self-directed learning, they become empowered and less dependent on external leadership. Learnership, for Cooksey, is part and parcel of organisational learning; a learning organisation only becomes such when a critical mass of its workers adopts the practices of learnership.

Based on her research on schools, Doig (2006) published a brief article in which she shared her model of learnership. As with other authors, she links learnership with leadership, and suggests that it is a necessary part of a culture of innovation and quality. It has, in her view, a future focus; it fosters intrinsic motivation; and it seeks to identify, analyse, and remove barriers to learning. Learnership depends on the skills of independence and self-direction; thus, educating for learnership must build these capabilities and dispositions. In her words, learnership means "living the habit of continuous self and school renewal" (p. 6). As with other sources on the subject, this article suggests that to change the system we must first change ourselves. Finally, Doig (2006) links learnership and resilience, basically the ability to "roll with the punches and keep on swinging" and become stronger through challenge.iii A challenge for educators and professional developers, then, is how do we best build resilience?

More recently, Kim and Hays (2010) and Hays and Kim (2012) frame learnership as one of the main emerging forms of leadership and a critical capability and disposition at the dawn of the new millennium. Learnership, embodied in the Leader as Learner and Teacher, is dedicated to learning and developing his or her knowledge, skills, and capacities, and committed to helping others learn and develop. These and other scholars in the area are concerned with adaptive capacity, the fortitude and foresight to deal with relentless change and anticipate and prepare for problems and opportunities before they arise. The Leader as Learner and Teacher seeks challenge and critique; celebrates mistakes for the lessons they provide; surfaces and revises assumptions, biases, beliefs, and habits that impede effectiveness; and builds sustainable capabilities for the future.

As this brief discussion reveals, scholars emphasise several significant aspects or foundations of learnership. And, while to date learnership has been situated within or related to leadership (and, to some extent, organisational learning), several of these elements seem particularly germane to Critical Learnership. Terms we would highlight from the preceding paragraphs include: lifelong learning and learning to learn; independence and autonomy; innovation and adaptation; adaptive capacity, resilience, and sustainability; renewal (with transformation of self and system implied); and organisational learning. 
While we don't see the term expressly, there are pervasive undertones of agency in the language above, not surprising perhaps given these scholars were writing about leaders and leadership. Additionally, there is a strong sense throughout these citations of accepting responsibility for learning and leveraging learning to promote positive change. The dedication to empowerment also seems clear. Learnership is about building the confidence, commitment, and capability to make a difference and to continually do so. Finally, we see that learnership is a purposeful, ongoing, and presumably necessary process of constructing and reconstructing meaning.iv This might mean, in the context of professional practice, reconceptualising purpose or relationships, or reinventing service delivery. We examine some of these dimensions of learnership and their interrelationships following this brief introduction to "criticality".

\section{Criticality}

The term critical is useful in this context due to two of its complementary connotations - analytical and crucial. Critical Learnership is enquiring, logical, systematic, careful, methodical, and rigorous. It seeks reason and reasonable, defensible grounds for assertions, conclusions, and decisions; and to dispel delusion, fallacy, and misconception. It seeks to surface, explore, and validate or supplant biases, beliefs, and assumptions that impede or undermine learning and change. This is absolutely necessary, or "critical" in dealing with novel and complex, wicked problems (Hays, 2013) and situations fraught with ambiguity and contestation, characteristic of dilemmas professional practitioners frequently face (Glatter et al., 1996; Noordegraaf, 2007). It is crucial that conclusions and decisions are arrived at based on objective consideration of the best, most complete information available, and that the process followed and criteria considered are explicit and defensible (Friedman, 2008).

It is unfortunate that critical also carries the pejorative connotation of disapproval or criticism. We exclude this latter derisive meaning when we speak of Critical Learnership. Whilst Critical Learnership seeks accuracy, truth, relevance, precision, objectivity, and other attributes of discriminating, discerning balanced critique, it would strive to minimise the debilitating, undermining effects of "critical" judgements, evaluations, and performance feedback. A significant implication in the pursuit of Critical Learnership is creating a culture where individuals effectively seek and make use of evidence that runs counter to beliefs, preferences, or current practices. Thus, it has a disruptive quality or influence (Tillmanns, 2016).

Critical is also often used to characterise circumstances that are grave, acute, or threatening, as in "The shortage of potable water is now critical." While we do not invoke this connotation with respect to Critical Learnership we might suggest that lack of Critical Learnership-that is, the absence of prudent forethought, sufficient analysis, and objectivity - can lead to such critical states. Finally, there is the notion of "critical mass" - the amount (number or kind) of an ingredient or constituent to make something work, which is particularly important in terms of sustainability. How many people practicing Critical Learnership, we might inquire, do we need to ensure our organisation or 
community survives and thrives? We do not know what the "critical mass" is, but it is doubtful that a modest minority will be sufficient.

In this context, the authors employ the term critical more or less as it is used in the literatures on critical thinking, ${ }^{11}$ critical pedagogy (Kincheloe, 2008; McLaren, 2015), and critical analysis or evaluation (Zepke, 2017)-basically pick a statement, proposal, argument, account, recommendation, or conclusion apart, and determine how reasonable, practicable, or plausible it is. Is there sufficient evidence? How objective is the analysis? Is there a balanced portrayal? Does it seem fair with respect to all stakeholders? We do not belabour notions of critical theory (Bronner, 2-17), though acknowledge that Critical Learnership is intentionally a strategy and philosophy for bettering organisations and communities through improved professional practice. ${ }^{12}$ Where biases, beliefs, assumptions, values, structural or systemic features, and established patterns of behaviour impinge upon or limit the welfare, development, or engagement of one or more group, Critical Learnership would seek-no doubt through participatory and collaborative means - to learn through and ultimately change the circumstances.

\section{Critical Thinking}

Critical Thinking is essential to solving complex problems and making difficult decisions-capabilities demanded of graduates in the professional work-world (Hays, 2015; Treleaven and Voola, 2008). It is sometimes held to be a prerequisite for engaged citizenship and democratic action (ten Dam and Volman, 2004; Jerome, 2017; Veugelers, 2007). Less lofty, Critical Thinking is probably a necessary skill and habit in the conduct of adult day-to-day life (see Mezirow, 2012, or Nosich, 2012). Critical Thinking has been persuasively linked to learning and vice versa, as suggested by scholars such as Fin (2011), Garrison (1992), Kreber (1998), and Profetto-McGrath (2005.

Critical Thinking involves a range of behaviours and attitudes, and the requisite skills, knowledge, and orientations that underlie them. These include: analysis, inference, interpretation, implication, explanation, evaluation, synthesis, application, and self-regulation (Facione, 1990); and attention, categorisation, selection, and judgement (Cottrell, 2011). Whitehead (2004) stipulates that Critical Thinking employs and is demonstrated through analysis and argument; and, as astutely observed by Finn (2011), decision-making is an instrumental quality of Critical Thinking (not just an output), along with interpretation, judgement, evaluation, metacognition, and the importance of evidence.

Barnett (1997) suggests that Critical Thinking involves knowledge construction and reconstruction, what he refers to as "reconstitution". As such, Critical Thinking has elements of creativity and openness to possibility (Seymour et al.,

\footnotetext{
11 See references cited in the Critical Thinking section below; refer to the recent massive sourcebook provided by Davies and Barnett (2015).

12 See any of the following for perspectives on and from critical theory: Brookfield (2005), Giroux (1997), Kincheloe and McLaren (2002), or Mezirow (1981).
} 
2003) and generativity (Bailin and Siegel, 2003; Bonk and Smith, 1998). It is constructive and action-oriented (Cope, 2003; Jenkins and Cutchens, 2011).

Jones (2015) specifies that Critical Thinking is a disciplined act. To be most useful, Critical Thinking must be purposeful, disciplined, and conscious; the thinker should be continually inclined to question, investigate, and challenge (Griffin, 2003; Green, 2015), persisting to reveal truth, reality, and wholeness in the face of difficulty (and, perhaps, when seemingly unnecessary). This may be the "critical spirit" some scholars discuss (e.g., Facione, 1990; Smith, 2003).

Along with discipline and disposition, Brookfield (2012) stresses that the Critical Thinker constantly seeks to surface and explore assumptions, the "taken for granteds" that so often beyond awareness cloud our thinking (see, also, Cope, 2003; Gray, 2007; and Hammond et al., 1998). Attentiveness, mindfulness, and reflection appear in many treatments of Critical Thinking (see Byrnes and Dunbar, 2014, Finn, 2011, Gray, 2007, and Kuhn, 1999, as examples). Critical Thinking is improbable without awareness. One must be attentive to both external stimuli and internal responses and states.

Another term that must apply to Critical Thinking is objectivity. One cannot be a Critical Thinker without a continuing attempt to remain objective (see Facione et al., 1995, or Garrison, 1992). Objectivity is the ability to remain unbiased, impartial, detached, and rational, affecting how we perceive and act. Seeing things as they are rather than how we might wish or fear they might be, or delude ourselves or be fooled into thinking they are, is a key attribute of the Critical Thinker (West et al., 2008). Training in Critical Thinking must cultivate an awareness of the susceptibility to fall victim to subjectivity and its dangers; hence the focus of many advisors regarding development of Critical Thinking on combatting effects of perceptual blinders, biases, assumptions, and beliefs (Garrison, 1992; Paul and Elder, 2001).

In an emerging conceptualisation, Hays (2017) distinguishes Critical Thinking from other higher-order thinking capabilities and dispositions and shows important relationships amongst reasoning, judgement, and reflective action (RJRA), perspective, complex and creative problem-solving, decision-making, planning, and implementation. This model attempts to account for sustainable professional effectiveness and continuous practice improvements, including how individuals and teams optimise learning and development.

Critical Learnership draws substantially from Critical Thinking and the capabilities, dispositions, and discipline on which it hinges. But just as Critical Thinking is necessary but insufficient on its own to effective, ethical, and sustainable professional practice, it accounts for only parts of learnership. More encompassing, the RJRA model discussed above shows promise in explaining intentional and mindful professional behaviour and practice effectiveness. Of special interest, here, is the notion of Reflective Action, or what the author refers to as Learning in the Moment. This, understood as part of a dynamic interactive system with possible virtuous cycle affects, offers potential for continuous learning and improvement. However, these authors thus far have failed to 
explore or exploit the "critical" aspects of learning at the individual level or professional practice arena.

Typical questions posed by the Critical Learnership practitioner in confronting a stubborn problem would be:

- What is holding us back from solving this problem?

- What are we not seeing? What are our "blindspots"?v

- What beliefs do we hold about the cause of the problem or potential remedies that nay need reconsidering?

- What are ten different lenses through which we can view the problem?

- Who are all the stakeholders contributing to or being affected by this problem, and how would they see and resolve it?

- How sure can we be that past efforts to solve the problem might not work if approached differently or given more time?

- On what can we afford to compromise, and why? What are the implications?

- What do we need to learn - or unlearn - to progress problem resolution?

These are merely indicative of a vast range of Critical Learnership questions. There would be many more. But these serve to illustrate a merging of critical thinking type questions with those directed towards learning.

While critical thinking proponents provide much helpful guidance for problemsolving, decision-making, and even learning, much room remains for the establishment of frameworks for professional practice learning and development that are purposeful, practicable, and sustainable, and that are solidly grounded in defensible and contemporary theory and empirical research. This is why we draw heavily on several key and interrelated concepts, including and notably sustainability, resilience, adaptive capacity, and agency, and the "critical" and mutually reinforcing role they play in learning. What we are after is a learning system that is self-directing and self-sustaining, both responsive and proactive.

Relationships amongst two or more of these elements (and others as shown in Figure 1) have already been identified and / or described in the literature. For example, very relevant to our work here, Clarke and Wilcockson (2000) explored relationships between organisational, professional, and practice learning. Boal and Hooijberg (2001) contributed significantly to leadership and organisational scholarship by promulgating their ideas on absorptive and adaptive capacities. Early proponents of organisational wisdom as well, they suggested that strategic leadership can largely be understood as the interaction of absorptive and adaptive capacities and wisdom. Not long after, Casey (2005) outlined the connection between adaptive capacity and organisational learning.

Walls and Jickling were already linking Critical Thinking and sustainable, meaningful learning in 2002, noting the importance of creating spaces and 
possibilities. In 2006, Avis and Freshwater underscored the relationship amongst Critical Thinking, Critical Reflection, and professional expertise and judgement. The brief but powerful article by Fazey et al. (2007) cogently links adaptive capacity, resilience, and sustainability, with learning to learn (and its metacognitive dimensions) as the essential enabler. They also provided guidance on components and design of learning that would be most fruitful; and, of particular relevance to professional practice development, addressing issues of transfervi and expertise. Then, in 2008, Pelling et al. provided insight into the contribution of social learning to organisational adaptive capacity, very relevant to professional practice learning and sustainability. Finally, Sterling (2010) clearly articulated important relationships amongst adaptive capacity, resilience, and transformational learning theory and their place in sustainability.

\section{Critical Reflection}

Given the attention focussed on reflection and reflective practice across professional practice, education, and management literatures 13 , including and especially literature drawn upon here with respect to metacognition, learning to learn, and self-directed learning (Carter and Townsend, 1994; Hays, 2015; ten Dam and Volman, 2004) and transformational learning (Harris et al., 2008; Mezirow, 2012; Sterling, 2010), it is necessary to at least briefly describe what we mean by critical reflection and situate it within Critical Learnership.

In many respects, critical reflection is like critical thinking. ${ }^{14}$ And, as we noted above, reflection is often included as an important component of critical thinking. Here, one aspect of reflection is thinking about thinking, or metacognition (Clayton and Ash, 2009; Kolb and Kolb, 2009). Similarly, and as applied to Critical Learnership, reflection involves thinking about learning and is thought to be an important part of learning to learn, or what we might call meta-learning (Carneiro, 2007; Hays, 2015). Reflection is what converts experience to learning (Anseel, 2017), and we postulate that critical reflection is what defines the lessons to be taken from the experience.

Critical reflection is also like critical thinking in that it adds a conscious rigour, or attentiveness and critical lens, to one's behaviour - both internal (in the head, heart, or gut) and external. But critical reflection is not just inwardly focussed. It attends to what is happening all around one, and the interactions between oneself and the environment-tasks and people. It is concerned with thoughts, feelings, and actions; and trying to understand what precisely is going on (and not), and why. Thus, a focus of critical reflection is meaning (see Leung and Kember, 2003), as illustrated by the following questions:

- What does this mean to me? What is its significance? What might it mean to others?

\footnotetext{
13 See Anzalone (2001), Cope (2003), Daley (2000), Gray (2007), or Mann et al. (2009) as examples.

14 They are not generally considered the same thing, but closely related and interdependent (see Ghanizadeh, 2017, or Jahn and Kenner, 2018).
} 
- Why am I behaving this way? What are the immediate consequences and longer-term implications of my behaviour?

- What is behind my feeling? What might be going on?

Again, these questions are merely indicative. They may or may not serve to promote readers' critical reflection. But, ultimately, questioning is at the heart of critical reflection; and critical reflection may significantly enhance critical thinking, as suggested by researchers such as Ghanizadeh (2017) and Watkins (2017). It is an open-minded enquiry that seeks to evaluate-though neither prejudge nor presuppose causality of - behaviour, what might be causing it, and what its outcomes are-and draw useful lessons from the evaluation. What can we learn from this? What do we need to do to be more effective?

To evaluate effectively, one must be objective, thorough, logical, and balanced; that is, approach critical reflection systemically and systematically, or analytically, thus highlighting the similarities between critical thinking and critical reflection. Key critically reflective questions here might include:

- How objective am I concerning this issue or its cause? How can I ascertain how objective I am being?

- What can I do to increase the objectivity of my evaluation? What data or other perspectives might help, and how can I obtain them?

- What beliefs or assumptions underlie my evaluation that remain implicit and need to be surfaced and tested for validity?

\section{Review}

This article introduces and explicates the emerging concept of Critical Learnership, a designation implying criticality and learning. Critical Learnership encompasses crucial ideas, principles, and practices, and is grounded in a blending of complementary theory. Key components of Critical Learnership include organisational learning practices, application of the theory and function of complex adaptive systems, sustainability principles, continuous practice improvement, and individual learning and development. In particular, Critical Learnership integrates notions of Critical Reflection and Critical Thinking. The latter two capabilities fuse to create or enable autonomous, purposeful, self-directing learners who operate effectively in ever-changing and increasingly-challenging circumstances. This, in brief, arises from an individual's objective attention to internal states and processes and external conditions and their constant interplay. Presumed is that as skills and dispositions of Critical Learnership increase, need for external controls and direction will reduce, and the individual or team will attain greater capacity to self-regulate effective and proactive learning, responsiveness, and adaptability. Ultimately, Critical Learnership is an evolutionary process and capability.

\section{Conclusions}

It would come as no surprise to most readers that continuous learning is an important element of professional practice. Learning contributes to individual 
effectiveness and career advancement. It is a necessary part of maintaining currency in the field, and to continual improvement of practice. It should be an ongoing team and practice process - and no doubt individuals and teams learn all of the time. However, it is our assertion that what and how professionals learn for and through practice, and to what effect, can be substantially and more predictably enhanced.

The need to accelerate and tailor learning, and make it more efficient, economical, and effective, is great. Some arguments are well known. The scope and pace of change, and advancements in technology and knowledge, for example, require professional practitioners to continually update procedural practices. Similarly, policy shifts and organisational restructuring require individuals and teams to change whom they work with and how. To make any headway against the wicked problems of our time demands new and concerted approaches we have never tried or failed to exploit, demanding collaborative learning. Then there is the desire, if not a compelling need, to improve practice and organisational effectiveness, to continually improve efficiencies and reduce costs - to do increasingly more with less.

Our response to these and other needs is Critical Learnership. Critical Learnership, as we have explained above, is a new way of thinking about and structuring learning. Its intent is to empower and enable individuals, teams, and communities to take more control for their learning than may typically be the case. This responds to a recognition that external direction and control of learning is costly, insufficient, and disempowering. It may actually fuel a vicious cycle of passivity or dependency (Hays, 2013). Critical Learnership also acknowledges that learners can be more motivated and engaged, and, thus, learn more effectively when they have a measure of control over what and how they learn, and when they take responsibility for that learning (Deci and Ryan, 2016).

With this article, the authors have tried to draw attention to a new learning paradigm-Critical Learnership-and the need for it. It is a complex model, comprised of many elements (see Table 1), many of which will be familiar to educators and professional development practitioners, management scholars, and those exposed to sustainability and systems thinking. The elements, per se, are not new, though their integration into one model of learning has not before been attempted.

Table 1. Aspects of Critical Learnership

\begin{tabular}{|lll|}
\hline - Sustainability & - Resilience & - Adaptive Capacity \\
- Agency & - Autonomy & - Capacity-Building \\
- Deep Learning & - Critical Thinking & - Critical Reflection \\
- Self-Directed & - Innovation & - Generative Learning \\
Learning & - Autonomy & - Transformational \\
- Metacognition & & Learning \\
\hline
\end{tabular}


Various linking of a few of the elements has already been accomplished, lending credibility to this more comprehensive model. The richest coupling of elements is evident in some of the organisational learning literature and in that concerning sustainability, both tending towards more systemic conceptualisations. Prime examples include: Applebaum and Goransson (1997), linking transformational and adaptive learning to organisational learning; Fazey et al. (2007), linking adaptive capacity, sustainability, resilience, learning to learn, and metacognition within a socioecological system perspective; Illeris (2003), linking adult, transformational, and transcendent learning to workplace and organisational learning.

A work in progress, the fullness of relationships amongst the elements has yet to be validated, but their place and role in the model are plausible. Learning is clearly linked to effective leadership and leadership development; professionalism and professional practice; active and able citizenship and democracy; adaptation and resilience; and innovation and transformation. Of particular value would be evidence that the elements work synergistically producing sustainable, virtuous cycles of learning and change. What is sought in a model like Critical Learnership is a learning system that is self-directing and self-sustaining, both responsive and proactive. Individuals and teams need to learn not just what they need at the moment to survive, but all that might help them and their organisations thrive long into the future.

\section{Directions for Further Research}

As an emerging concept, there are many possible and needed avenues of research into Critical Learnership. Here, we outline just four.

Components and relative influence of Critical learnership. We have identified 15 elements of Critical Learnership, as presented in Figure 1 and Table 1, elaborating on some, particularly Critical Thinking and Critical Reflection, and referring to the others, with emphasis on autonomy, agency, and sustainability. Our research suggests these each have an integral place in the model of Critical Learnership, but there may be others that should be included. It is unclear how complete and correct the pieces, how harmonious their synergy, or what their respective and relative contributions are. Research is needed to elucidate Critical Learnership as a complete and operating system and define its scope and the interrelationships amongst the elements.

Efficacy of autonomous self-directed learning. It is one thing to submit that individuals and teams can and should take more control of their own learning. It is another thing entirely to find or create the most supportive mechanisms to do so, or to ensure individuals and teams possess and are disposed to use the skills to make the most of the mechanisms. Research is needed on the core skills, dispositions, and mechanisms required and how to assess and develop them.

Right balance and tension between directed and self-directed learning. For a variety of reasons, people differ in their levels of self-direction and readiness to 
assume greater responsibility and control. Teachers and managers also differ in their readiness to delegate responsibility and facilitate self-directed learning. Readiness depends on a range of factors, including skills, beliefs, and structural features. Conditions need to be understood in order to strike a useful balance between what people can should be doing to learn and promote learning, given where they are and where they might strive to be. Research is needed to determine precisely what these conditions are and what or how a positive level of tension can be created and maintained such that learners are continually improving their ability to effectively govern their learning (over time, reducing need for external direction and control).

Critical Learnership as set of skills, dispositions, and behaviours. Belief in the ideals and aspirations of self-governance, empowerment, autonomy, agency, initiative, and criticality is an important starting point, but provides little guidance as to what exactly the individual, team, or organisation must possess and demonstrate to qualify as a critical learner or promoter of Critical Learnership. Research is required to better identify, describe, and define the most relevant skills, dispositions, and behaviours. A useful place to begin, it seems, would be to identify then investigate individuals and organisations that appear to be continually and proactively learning, innovating, and reinventing themselves. How do they do this? What do they have that provides advantage?

\section{Parting Thoughts}

The main contribution of Critical Learnership is the notion that learning can and should be sustainable. That will never happen until those who need to learn (all of us) accept responsibility for learning and acquire the skills and habits to do so. If what is "taught" and who teaches remain in the hands of the few, the many may never develop the confidence, skill, and disposition to learn what it takes to improve themselves. The many are unlikely to become effective agents of change in their organisations or productive contributors to society if they cannot transcend limitations in thinking and learning. Critical Learnership provides the motivation and mechanisms to undo impediments, see new possibilities, and reinvent self and practice. It acknowledges that we are always perfectly incomplete: works in progress striving continually toward a better future of our own making.vii

\section{References}

Anseel, F. (2017). Agile learning strategies for sustainable careers: a review and integrated model of feedback-seeking behavior and reflection. Current Opinion in Environmental Sustainability, Vol. 28, pp. 51-57.

Anzalone, F. (2001). It all begins with you: improving law school learning through professional self-awareness and critical reflection. Hamline Law Review, Vol. 24, pp. 324-371.

Appelbaum, S., and Goransson, L. (1997). Transformational and adaptive learning within the learning organization: a framework for research and application. The Learning Organization, Vol. 4, No. 3, pp. 115-128.

Avis, M., and Freshwater, D. (2006). Evidence for practice, epistemology, and critical reflection. Nursing Philosophy, Vol. 7, pp. 216-224. 
Bailin, S., and Siegel, H. (2003). Critical Thinking (Ch. 10). In Blake, N., Smeyers, P., Smith, R., and Standish, P. (Eds.), The Blackwell Guide to the Philosophy of Education, pp. 181-193.

Barnett, R. (1997). Higher Education: A Critical Business. McGraw-Hill Education (UK).

Becker, K. (2005). Individual and organisational unlearning: directions for future research. International Journal of Organisational Behaviour, Vol 9, No. 7, pp. 659670.

Boal, K., and Hooijberg, R. (2001). Strategic leadership research: moving on. The Leadership Quarterly, Vol. 11, No. 4, pp. 515-549.

Bonk, C., and Smith, G. (1998). Alternative instructional strategies for creative and critical thinking in the accounting curriculum. Journal of Accounting Education, Vol. 16, No. 2, pp. 261-293.

Bronner, S. (2017). Critical theory: A very short introduction. Oxford University Press.

Brookfield, S. (2005). The Power of Critical Theory for Adult Learning and Teaching. Maidenhead, UK: Open University Press.

Brookfield, S. (2008). Developing critical thinkers: challenging adults to explore alternative ways of thinking and acting. San Francisco, CA: Jossey-Bass.

Brookfield, S. (2012). Teaching for critical thinking: tools and techniques to help students question their assumptions. San Francisco, CA: Jossey-Bass.

Byrnes, J., and Dunbar, K. (2014). The nature and development of critical-analytic thinking. Education Psychology Review, Vol. 26, pp. 477-493.

Camillus, J. (2008). Strategy as a wicked problem. Harvard Business Review, Vol. 86, No. 5, pp. 98-107.

Carneiro, R. (2007). The big picture: understanding learning and meta-learning challenges. European Journal of Education, Vol. 42, No. 2, pp. 151-172.

Carter, V., and Townsend, K. (1994). Leadership: do adult educators know the secret ingredient? Paper presented at the Pennsylvania Adult \& Continuing Education Research Conference, Monroeville, PA, 8 October. In Dean, G., and Ferro, T. Proceedings. Indiana University of Pennsylvania, pp. 49-55.

Casey, A. (2005). Enhancing individual and organizational learning: a sociological model. Management Learning, Vol. 36, No. 2, pp. 131-147.

Clarke, C., and J. Wilcockson. (2000). Professional and organizational learning: analysing the relationship with the development of practice. Journal of Advanced Nursing, Vol. 34, No. 2, pp. 264-272.

Clayton, P., and Ash, S. (2009). Generating, deepening, and documenting learning: the power of critical reflection in applied learning. Journal of Applied Learning in Higher Education, Vol. 1, Fall, pp. 25-48.

Conway, M., and Futures, T. (2009). Strategic Thinking: What it is and How to Do it. Downloadable

at: http://s3.amazonaws.com/academia.edu.documents/46986171/Strategic_Thin king_what_it_is_and_how_to20160703-2199919zq9pu.pdf?AWSAccessKeyId=AKIAIWOWYYGZ2Y53UL3A\&Expires=148622 3250\&Signature=1vEuZvV1yHpbEDVYUaM51N84oS8\%3D\&response-contentdisposition=inline \%3B\%20filename\%3DStrategic_Thinking_what_it_is_and_ho W_to.pdf

Cooksey, R. (2003). "Learnership" in complex organisational textures. Leadership $\mathcal{E}$ Organization Development Journal, Vol. 24, No. 4, pp. 204-214.

Cope, J. (2003). Entrepreneurial learning and critical reflection: discontinuous events as triggers for 'higher-level' learning. Management Learning, Vol. 34, No. 4, pp. 429 450.

Cottrell, S. (2011). Critical Thinking Skills: Developing Effective Analysis and Argument. Palgrave Macmillan. 
Coutu, D. (2002). How resilience works. Harvard Business Review, Vol. 80, No. 5, pp. 4656.

Cörvers, R., Wiek, A., de Kraker, J., Lang, D. J., and Martens, P. (2016). Problem-based and project-based learning for sustainable development. In Sustainability Science (pp. 349-358). Springer Netherlands.

Daley, B. (2000). Learning in professional practice. New Directions for Adult and Continuing Education (Ch. 4), No. 86, Summer, pp. 33-42.

Davies, M., and Barnett, R. (Eds.). (2015). The Palgrave Handbook of Critical Thinking in Higher Education. New York: Palgrave Macmillan.

Davis, M. A. (2009). Understanding the relationship between mood and creativity: a meta-analysis. Organizational Behavior and Human Decision Processes, Vol. 108, No. 1, pp. 25-38.

Deci, E., and Ryan, R. (2016). Optimizing students' motivation in the era of testing and pressure: a self-determination theory perspective. In Building Autonomous Learners (pp. 9-29). Springer Singapore.

Derrick, M., and Carr, P. (2003). Facilitating and understanding autonomy in adult learners. New Horizons in Adult Education and Human Resource Development, Vol. 17, No. 2, pp. 4-10.

Disterheft, A., Caeiro, S., Azeiteiro, U. M., and Leal Filho, W. (2015). Sustainable universities: a study of critical success factors for participatory approaches. Journal of Cleaner Production, Vol. 106, pp. 11-21.

Doig, C. (2006). Keeping the fleas motivated. Downloaded from educational leaders.govt.nz at: https://scholar.google.co.nz/scholar?hl=en\&q=Doig+fleas\&btnG=\&as_sdt=1\% 2C5\&as_sdtp.

Dunne, G. (2015). Beyond critical thinking to critical being: criticality in higher education and life. International Journal of Educational Research, Vol. 71, pp. 86-99.

Facione, P. (1990). Critical thinking: a statement of expert consensus for purposes of educational assessment and instruction. Research findings and recommendations. Millbrae, CA. Retrieved from https://assessment.trinity.duke.edu/documents/Delphi_Report.pdf

Fazey, I., Fazey, J. A., Fischer, J., Sherren, K., Warren, J., Noss, R., and Dovers, S. (2007). Adaptive capacity and learning to learn as leverage for social-ecological resilience. Frontiers in Ecology and the Environment, Vol. 5, No. 7, pp. pp. 375-380.

Finn, P. (2011). Critical thinking: knowledge and skills for evidence-based practice. Language, Speech, and Hearing Services in Schools, Vol. 42, pp. 69-72.

Flood, R. L. (2010). The relationship of 'systems thinking' to action research. Systemic Practice and Action Research, Vol. 23, No. 4, pp. 269-284.

Friedman, V. (2008). Action Science: Creating Communities of Inquiry in Communities of Practice. Sage Publications.

Funke, J., Fischer, A., and Holt, D. (2018). Competencies for complexity: problem solving in the twenty-first century. In Assessment and Teaching of 21st Century Skills (pp. 41-53). Springer.

Garrison, D. (1992). Critical thinking and self-directed learning in adult education: an analysis of responsibility and control issues. Adult Education Quarterly, Vol. 42, No. 3, pp. 136-148.

Geiger, D., and Antonacopoulou, E. (2009). Narratives and organizational dynamics: exploring blind spots and organizational inertia. The Journal of Applied Behavioral Science, Vol. 45, No. 3, pp. 411-436.

Geldhof, G., Fenn, M., and Finders, J. (2017). A self-determination perspective on selfregulation across the life span. In Development of Self-Determination through the Life-Course (pp. 221-235). Springer Netherlands. 
Ghanizadeh, A. (2017). The interplay between reflective thinking, critical thinking, selfmonitoring, and academic achievement in higher education. Higher Education, Vol. 74, No. 1, pp. 101-114.

Giroux, H. (1997). Pedagogy and the Politics of Hope: Theory, Culture, and Schooling, a Critical Reader. Westview Press.

Glatter, R., Jacobson, S., and Hickox, E. (1996). Managing dilemmas in education: the tightrope walk of strategic choice in autonomous institutions (pp. 18-29). School Administration: Persistent Dilemmas in Preparation and Practice. Westport: Praeger.

Gray, D. (2007). Facilitating management learning: developing critical reflection through reflective tools. Management Learning, Vol. 38, No. 5, pp. 495-517.

Green, P. (2015). Teaching critical thinking for lifelong learning (Ch. 7; pp. 107-121). In Davies, M., and Barnett, R. (Eds.), The Palgrave Handbook of Critical Thinking in Higher Education. New York: Palgrave Macmillan.

Griffin, M. (2003). Using critical incidents to promote and assess reflective thinking in preservice teachers. Reflective Practice, Vol. 4, No. 2, pp. 207-220.

Hammond, J., Keeney, R., and Raiffa, H. (1998). The hidden traps in decision making. Harvard Business Review, Sep-Oct (Reprint 98505; OnPoint 5408), pp. 2-11.

Hargadon, A. (2002). Brokering knowledge: linking learning and innovation. Research in Organizational Behavior, Vol. 24, pp. 41-85.

Harris, S., Lowery-Moore, H., and V. Farrow. (2008). Extending transfer of learning theory to transformative learning theory: a model for promoting teacher leadership. Theory into Practice, Vol. 47, pp. 318-326.

Hawe, P., Noort, M., King, L., and Jordens, C. (1997). Multiplying health gains: the critical role of capacity-building within health promotion programs. Health Policy, Vol. 39, No. 1), pp. 29-42.

Hays, J. (2010). The ecology of wisdom. Management \& Marketing, Vol. 5, No. 1, pp. 71.

Hays, J. (2013). Wicked problem: educating for complexity and wisdom (Ch. 6; pp. 134150). In Thompson, M., and D. Bevan (Eds.), Wise Management in Organisational Complexity. Basingstoke: Palgrave Macmillan.

Hays, J. (2014). Reasoning, judgement, and reflective action: a model for curriculum innovation and proposed collaborative research in the Pacific region. Paper presented at the Unitec Pacific Research Symposium, Auckland, New Zealand, 26 November.

Hays, J. (2015). Chaos to Capability: Educating Professionals for the 21st Century. Auckland: Unitec e-Press.

Hays, J. (2017). A wise course: educating professionals for the $21^{\text {st }}$ century, (Ch. 9). In Küpers, W., and Gunnlaugson, O. (Eds.), Wisdom Learning: Perspectives of 'Wising $U p^{\prime}$ Management Education. Farnham: Gower.

Hays, J., and Kim, C. (2012). Transforming Leadership for the 21st Century. Xlibris.

Hoy, W., and Tarter, C. (2010). Swift and smart decision making: heuristics that work. International Journal of Educational Management, Vol. 24, No. 4, pp. 351-358.

Illeris, K. (2003). Workplace learning and learning theory. Journal of Workplace Learning, Vol. 15, No. 4, pp. 167-178.

Jahn, D., and Kenner, A. (2018). Critical thinking in higher education: how to foster it using digital media. In The Digital Turn in Higher Education (pp. 81-109). Springer.

Jenkins, D., and Cutchens, A. (2011). Leading critically: a grounded theory of applied critical thinking in leadership studies. Journal of Leadership Education, Vol. 10, No. 2, pp. 1-21.

Jepson, E. (2001). Sustainability and planning: diverse concepts and close associations. Journal of Planning Literature, Vol. 15, No. 4, pp. 499-510. 
Jerome, L. (2017). What do citizens need to know? An analysis of knowledge in citizenship curricula in the UK and Ireland. Compare: A Journal of Comparative and International Education, 1-17.

Jones, A. (2015). A disciplined approach to critical thinking. In Barnett, R., and Martin, D. (Eds.), The Palgrave Handbook of Critical Thinking in Higher Education. New York, NY: Palgrave Macmillan.

Kahn, F. (2006). Auditory processing disorders: training curriculum for communication pathologists within the South African context. Unpublished master's thesis, University of Pretoria. Downloaded at: http://repository.up.ac.za/bitstream/handle/2263/23990/dissertation.pdf?seq $\underline{\text { uence }=1}$

Kaiser, L., Kaminski, K., and Foley, J. (Eds.). (2013). Learning Transfer in Adult Education. New Directions for Adult and Continuing Education, Vol. 137. John Wiley \& Sons.

Kim, C., and Hays, J. (2009). Renaissance leaders: global trends and emerging forms of leadership. i-Manager's Journal on Management, Vol. 4, No. 3, pp. 1-.

Kincheloe, J. (2008). Critical Pedagogy. New York: Peter Lang.

Kincheloe, J., and McLaren, P. (2002). Rethinking critical theory and qualitative research. In Zou, Y., and Trueba, E. (Eds.), Ethnography and Schools: Qualitative Approaches to the Study of Education, Ch. 5, pp. 87-138.

Kolb, A., and Kolb, D. (2009). The learning way: meta-cognitive aspects of experiential learning. Simulation \& Gaming, Vol. 40, No. 3, pp. 297-327.

Krasny, M., Lundholm, C., and Plummer, R. (2010). Resilience in social-ecological systems: the roles of learning and education. Environmental Education Research, Vol. 16, No. 5-6, pp. 463-474.

Kreber, C. (1998). The relationships between self-directed learning, critical thinking, and psychological type, and some implications for teaching in higher education. Studies in Higher Education, Vol. 23, No. 1, pp. 71-86.

Kuhn, D. (1999). A developmental model of critical thinking. Educational Researcher, Vol. 28, No. 2, pp. 16-26.

Kusano, S., Wright, M., and Conger, A. (2016). Development and assessment of selfagency, and the ability to innovate and take risks. Center for Research on Learning and Teaching Occasional Paper 34. Engaged Learning: Transforming Learning for a Third Century No. 3, University of Michigan.

Leung, D., and Kember, D. (2003). The relationship between approaches to learning and reflection upon practice. Educational Psychology, Vol. 23, No. 1, pp. 61-71.

Maitlis, S., and Sonnenshein, S. (2010). Sensemaking in crisis and change: inspiration and insights from Weick (1988). Journal of Management Studies, Vol. 47, No. 3, pp. 551580.

Mann, K., Gordon, J., and MacLeod, A. (2009). Reflection and reflective practice in health professions education: a systematic review. Advances in Health Sciences Education, Vol. 14, No. 4, pp. 595-621.

Martins, A., Martins, I., and Pereira, O. (2017). Embracing innovation and creativity through the capacity of unlearning. Handbook of Research on Human Resources Strategies for the New Millennial Workforce, pp. 128-147.

McGregor, S. (2012). Complexity economics, wicked problems and consumer education. International Journal of Consumer Studies, Vol. 36, No. 1, pp. 61-69.

McLaren, P. (2015). Life in Schools: An Introduction to Critical Pedagogy in the Foundations of Education. Routledge.

McLoughlin, C., and Lee, M. (2008). Future learning landscapes: transforming pedagogy through social software. Innovate: Journal of Online Education, Vol. 4, No. 5, pp. 111.

Mezirow, J. (1981). A critical theory of adult learning and education. Adult Education, Vol. 32, No. 1, pp. 3-24. 
Mezirow, J. (2012). Learning to think like an adult: core concepts of transformation theory. In P. Cranton and E. Taylor (Eds.), Handbook of Transformative Learning: Theory, Research, and Practice (pp. 73-97). San Francisco: Jossey-Bass.

Miller-Young, J., and Boman, J. (2017). Uncovering ways of thinking, practicing, and being through decoding across disciplines. New Directions for Teaching and Learning, Vol. 150, pp. 19-35.

Mitchell, I. K., and Walinga, J. (2017). The creative imperative: the role of creativity, creative problem solving and insight as key drivers for sustainability. Journal of Cleaner Production, Vol. 140, pp. 1872-1884.

Montoya, J., Pimm, S., and Solé, R. (2006). Ecological networks and their fragility. Nature, Vol. 442, pp. 259-264.

Murphy, D., and Toomey, F. (1993). Learnership / leadership model: "travelling into the 21st century." Paper presented at the $13^{\text {th }}$ International Conference on Critical Thinking, Rohnert Park, CA. Reference downloaded from ERIC at: http://eric.ed.gov/?id=ED362570

Natri, T. (2007). Active learnership in continuous self-and peer-evaluation. In Reconstructing Autonomy in Language Education (pp. 108-119). Palgrave Macmillan UK.

Nixon, S., and A. Murr. (2006). Practice learning and the development of professional practice. Social Work Education, Vol. 25, No. 8, pp. 798-811.

Noordegraaf, M. (2007). From "pure" to "hybrid" professionalism: present-day professionalism in ambiguous public domains. Administration \& Society, Vol. 39, No. 6, pp. 761-785.

Nosich, G. (2012). Learning to Think Things Through: A Guide to Critical Thinking across the Curriculum (4th Ed). Boston: Pearson.

Pelling, M., High, C., Dearing, J., and Smith, D. (2008). Shadow spaces for social learning: a relational understanding of adaptive capacity to climate change within organisations. Environment and Planning, Vol. 40, No. 4, pp. 867-884.

Potter, C., and Brough, R. (2004). Systemic capacity building: a hierarchy of needs. Health Policy and Planning, Vol. 19, No. (5), pp. 336-345.

Profetto-McGrath, J. (2005). Critical thinking and evidence-based practice. Journal of Professional Nursing, Vol. 21, No. 6, pp. 364-371.

Ramirez, G. (2012). Sustainable development: paradoxes, misunderstandings and learning organizations. The Learning Organization, Vol. 19, No. 1, pp. 58-76.

Reiter-Palmon, R., and Illies, J. (2004). Leadership and creativity: understanding leadership from a creative problem-solving perspective. The Leadership Quarterly, Vol. 15, No. 1, pp. 55-77.

Richmond, B. (1993). Systems thinking: critical thinking skills for the 1990s and beyond. System Dynamics Review, Vol. 9, No. 2, pp. 113-133.

Richards, C. (2015). Outcomes-based authentic learning, portfolio assessment, and a systems approach to" complex problem-solving": related pillars for enhancing the innovative role of PBL in future higher education. Journal of Problem Based Learning in Higher Education, Vol. 3, No. 1, pp. 78-95.

Rowley, J., and Gibbs, P. (2008). From learning organization to practically wise organization. The Learning Organization, Vol. 15, No. 5, pp. 356-372.

Schwandt, D. (2005). When managers become philosophers: integrating learning with sensemaking. Academy of Management Learning \& Education, Vol. 4, No. 2, pp. 176-192.

Selby, D. (2000). A darker shade of green: the importance of ecological thinking in global education and school reform. Theory into Practice, Vol. 39, No. 2, pp. 88-96.

Seymour, B., Kinn, S., and Sutherland, N. (2003). Valuing both critical and creative thinking in clinical practice: narrowing the research-practice gap? Journal of Advanced Nursing, Vol. 42, No. 3, pp. 288-296. 
Shaw, R. (2016). The logic and limits of leadership blindspots. Leader to Leader, Vol. 80, pp. 12-17.

Sheffi, Y. (2005). The Resilient Enterprise: Overcoming Vulnerability for Competitive Advantage. Cambridge, MA: MIT Press.

Smith, G. F. (2003). Beyond critical thinking and decision making: teaching business students how to think. Journal of Management Education, Vol. 27, No. 1, pp. 24-51.

Sterling, S. (2010). Learning for resilience, or the resilient learner? Towards a necessary reconciliation in a paradigm of sustainable education. Environmental Education Research, Vol. 16, No. 5-6, pp. 511-528.

Sveiby, K., Gripenberg, P., Segercrantz, B., Eriksson, A., and Aminoff, A. (2009). Unintended and undesirable consequences of innovation. In XX ISPIM Conference, "The Future of Innovation". Vienna, Austria (April).

ten Dam, G., and Volman, M. (2004). Critical thinking as a citizenship competence: teaching strategies. Learning and Instruction, Vol. 14, No. 4, pp. 359-379.

Tenkasi, R., and Boland, R. (1993). Locating meaning making in organizational learning: the narrative basis of cognition. Research in Organizational Change and Development, Vol. 7, pp. 77-103.

Tillmanns, T. (2017). Disruptive learning: re-orienting frames of mind towards becoming sustainability change agents. Doctoral dissertation, Dublin City University.

Tomlin, K., Metzger, M., Bradley-Geist, J., and Gonzalez-Padron, T. (2017). Are students blind to their ethical blind spots? an exploration of why ethics education should focus on self-perception biases. Journal of Management Education, Vol. 41, No. 4, pp. 539-574. https://doi.org/10.1177/1052562917701500.

Treleaven, L., and Voola, R. (2008). Integrating the development of graduate attributes through constructive alignment. Journal of Marketing Education, Vol. 30. No. 2, pp. 160-173.

Veugelers, W. (2007). Creating critical-democratic citizenship education: empowering humanity and democracy in Dutch education. Compare: A Journal of Comparative and International Education, Vol. 37, No. 1, pp. 105-119.

Walls, A., and Jickling, B. (2002). "Sustainability" in higher education: from doublethink and newspeak to critical thinking and meaningful learning. International Journal of Sustainability in Higher Education, Vol. 3, No. 3, pp. 221-232.

Watkins, M. (2017). Fostering deep learning and critical thinking amongst net generation learners. In Contemporary Research in Technology Education (pp. 23-37). Springer Singapore.

West, R., Toplak, M., and Stanovich, K. (2008). Heuristics and biases as measures of critical thinking: associations with cognitive ability and thinking dispositions. Journal of Educational Psychology, Vol. 100, No. 4, pp. 930-941.

Whitehead, D. (2004). Top Tools for Teaching Thinking. Auckland: Pearson Education.

Zepke, N. (2017). Supporting engagement through critical evaluation. In Student Engagement in Neoliberal Times (pp. 169-186). Springer Singapore. 
${ }^{i}$ Agency is a key aspect of Critical Learnership. Having diverse meanings in practice and the literature, sometimes vague or conflicting, agency must be briefly explained as used here. We consider agency from a social-psychology perspective (see, for example, Evans, 2017), that is, as an individual and collective experience and expression of power, as enacted within a dynamic and interactive environment or context. Whilst readers, practitioners, and other researchers may disagree, we see agency not merely as a capacity but also a disposition to think and act in reasonable, responsive, and responsible ways, adjusting and adapting to situations and environment, and demonstrating self-direction. This involves, amongst other things, the ability and will to "read" the environment (seek information and interpret signals), problem-solve, decide, plan, evaluate and correct, and learn from experience. Related terms include autonomy, self-reliance, confidence and capability, initiative and proaction. One gets a sense for related and relevant usage in Natri's (2007) article linking learnership, evaluation, and autonomy. Refer to Geldhof et al. (2017) and Kusano et al. (2016) for contemporary works that reflect this portrayal.

ii The reference we cite $(\mathrm{Kahn}, 2006)$ serves as an example of the many published sources on learnership as used in South Africa. More to the point, Kahn (2006) actually uses the term "Critical Learnership" (p. 62), so it has been previously introduced, though remains till now unexplored. Unfortunately, Kahn does not define or explain what she means by Critical Learnership, perhaps assuming it would be widely understood and only alluding to its importance. A read around the edges in Kahn's thesis might be reasonably interpreted to mean critical, context-appropriate application of theory and learned practice-which is certainly relevant to the way we use the construct and would apply across the gamut of professional practices.

iii See Coutu (2002), Sheffi (2005), or Sterling (2010) for more on resilience. Sterling's (2010) article is particularly germane to our views on learnership and its development as he relates learning, adaptability, transformation, and sustainability to resilience. His depiction of the resilient learner is consistent with our attributes of learnership. Krasny et al.'s (2010) framing of a special issue in Environmental Education Research provides a good overview of linkages between learning, resilience, and change in social-ecological systems within a context of sustainability.

iv See Maitlis and Sonnenshein (2010) or Schwandt (2005) for more on sensemaking and meaning making. Early on, Tenkasi and Boland (1993) linked meaning-making, organisational learning, and cognition with respect to organisational change. Daley (2000) has linked constructivism and transformational learning to meaning-making through the process of critical reflection. Finally, see Miller-Young and Boman's (2017) insightful work on constructing, deconstructing, and reconstructing thinking and learning

v See Geiger and Antonacopoulou (2009) for an interesting and relevant article on blindspots. Given our interests in the development of higher-order thinking capabilities and dispositions in young professionals, we refer readers, also, to Tomlin et al.'s (2017) article. Shaw (2016) presents a practical and timely discussion of leadership blindspots.

vi Transfer is an important concept and process in learning. Transfer is evidenced when an individual can apply knowledge or skill gained in one context to another, to a new and different problem or to a problem presenting in novel circumstances. To do so requires some aspects of creativity, resourcefulness, flexibility, and adaptability (and generally hinges on "deep learning". Knowing when, what, and how to transfer learning is an important function of Critical Learnership, as is caution with respect to what might be unwise to transfer. See Harris et al. (2008), Kaiser et al. (2013), or Nixon and Murr (2006) for helpful treatments on learning transfer. 
vii "I'm perfectly incomplete... still working on my masterpiece" provides a contemporary and provocative introduction to the concept of Critical Learnership. It acknowledges the perfection of a journey toward mastery that perhaps cannot and certainly should not ever be completed, but that must be continued. As long as one knows there is much to learn and that professional practice is always "a work in progress" that must be deliberately, enthusiastically, and unerringly pursued, and actively pursues it, then incompletion is perfect. The lyric conveys the personal ownership of an ongoing process leading to betterment of self, and, by extension, of society. It suggests that the learning journey towards greater capability and capacity is one of self-construction-building myself and, in collaboration with my team and other stakeholders, my practice and my community. 